\title{
Conception of ecocity with ecological infrastructure
}

\author{
Tetior Alexander \\ Building Department, Moscow, Russia
}

Email address:

atetior@mail.ru

\section{To cite this article:}

Tetior Alexander. Conception of Ecocity with Ecological Infrastructure. American Journal of Environmental Protection. Vol. 3, No. 5, 2014, pp. 244-248. doi: 10.11648/j.ajep.20140305.16

\begin{abstract}
Wide conception of «zero» eco-buildings and of «zero» ecocities with ecological infrastructure is based on three principles: «zero» interference in the nature, «zero» consumption of consumable resources from state networks, «zero» emission of pollution. «Zero» interference in the nature is the «zero» built-up area of buildings; it includes the minimal interference to natural circulation of matter, to migrations of animals; it signifies the sensory likeness to nature (use of sensory ecology - visual, odor and sound ecology); gardening of buildings, etc. «Zero» consumption of consumable resources includes: energy economy; renewable electric and thermal energy generation; natural ventilation and air-conditioning without energy consumption; decrease of expenses for internal illumination; reduction of water consumption, etc. «Zero» emission of pollution includes «zero» life cycle of buildings, recycling of waste products, use of ecological and recycled materials, the «zero» water drain, etc. The basis of «zero» eco-buildings and ecocities creation is architectural-building ecology with ecological infrastructure (it is complex of natural resources, constructions and systems, providing support of environment of human life at all levels - from the whole country up to cities and to separate buildings). Environment of life and environments of «zero» buildings and cities must be subject to all-embracing ecologization. All-embracing ecologization is system of upbringing of ecological thinking for respective activity and for use of ecological decisions based on ecological postulates, ecological philosophy and ethics, principles of sustainable building, adoption into account ethnical and geographical traits, social-psychological and social-economical features of inhabitants in city. This ecologization is the hierarchical system (from global up to local).
\end{abstract}

Keywords: Zero Eco-buildings, Ecocities, Ecologization, Ecological Infrastructure, Ecological Thinking, Intellectual Cities

\section{Introduction}

Table 1. Principles of creation of «zero» ecocities and eco-buildings

\begin{tabular}{|c|c|c|}
\hline \multicolumn{3}{|c|}{ Three principles of creation of «zero» ecocities and eco-buildings } \\
\hline «Zero» interference in the nature & $\begin{array}{l}\text { «Zero» consumption of consumable resources from } \\
\text { city networks }\end{array}$ & «Zero» emission of pollution \\
\hline «Zero» built-up area of buildings & $\begin{array}{l}\text { Use of natural technologies in lighting, } \\
\text { ventilation, conditioning, etc. }\end{array}$ & $\begin{array}{l}\text { Use of ecological life cycle by creation and } \\
\text { maintenance of buildings and cities }\end{array}$ \\
\hline Overground and underground buildings & Energy-active buildings & Use of ecological and recycled building materials \\
\hline Sensory likeness of built-up territory to nature & Energy-efficient buildings & $\begin{array}{l}\text { Use of systems of renewable energy from } \\
\text { bio-waste }\end{array}$ \\
\hline $\begin{array}{l}\text { Minimal interference to natural circulation of } \\
\text { matter }\end{array}$ & Reduction of water consumption & Use of systems of biological purification of waste \\
\hline $\begin{array}{l}\text { Planting of greenery of all artificial surfaces of } \\
\text { buildings }\end{array}$ & Renewable thermal energy generation & «Zero» water drain \\
\hline Support of being of small animals and birds & Utilization of thermal waste & Utilization of all waste \\
\hline $\begin{array}{l}\text { Creation of green corridors for support of } \\
\text { biological variety }\end{array}$ & \multicolumn{2}{|c|}{ Use of intelligent (clever) systems in building and city for achievement of «zero» effect } \\
\hline
\end{tabular}

Three principles of wide conception of «zero» eco-buildings and of «zero» ecocities creation include the following important parts of positive interaction of mankind with nature: «zero» interference in the nature; «zero» 
consumption of consumable resources from city networks; «zero» emission of pollution. Every part consists of several factors (tab. 1). One of the most important factors is preservation of landscapes with soil - vegetative layer from buildings and engineering structures. The surface of the ground in ecocity should be free; it may be filled by natural and cultural landscapes, and exempted from transport (fig. 1).

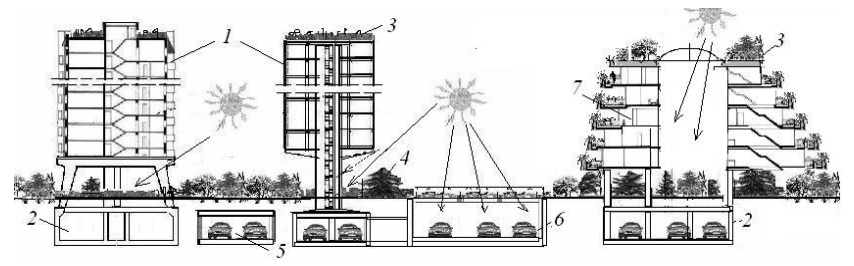

Figure 1. Scheme of "zero" ecocity with eco-buildings: 1 - overground buildings: 2 - underground parts of buildings; 3 - green roof; 4 soil-vegetable layer; 5 -underground structures; 6-underground street with sun lighting; 7 - "green hill".

This problem can be solved by overground and underground construction. «Zero» ecocities with eco-buildings may include all components of natural landscapes; all complex of protected natural territories; all technosphere, all directions of human activity - architecture, construction, industry, power, transport, water supply, removal and processing of waste products; socio psychological and socio - economic environment; ecological satisfaction of needs of inhabitants. Ideological base of «zero» ecocities creation should be ecological postulates.

\section{Results of Investigation}

It is possible to believe, that the «zero» ecocities with eco-buildings with equality between their citizens can be created by help of new scientific complex inclusive urban ecology, architectural ecology, building ecology, ecological infrastructure, resilience of life in city, sensory ecology, ecological philosophy, ecological ethics, socio-psychological and socio-economic decisions [1-9]. This new scientific complex and its usage will allow to create ecological healthy cities and settlements, to stop retreat of nature, and to achieve a state of ecological equilibrium. Urban, architectural and building ecology is interconnected sciences about making of settlements and buildings, which are in balance with nature, and allow creating high-quality environment in region, cities and in buildings. These purposes are achieved by ecological decision of territorial, planning, geological, geographical, biological, hygienic, architectural, technical and aesthetic problems starting with general town planning scheme and ending with construction of biopositive buildings. Solution set includes many directions of ecological construction, from biopositive buildings for preservation of soil-vegetable layer with flora and fauna, to backing of flora and fauna by help of creation of ecological framework, etc. (tab. 2) The new scientific complex should help to solve problems of «zero» ecocity and eco-buildings creation, including at gradual ecological reconstruction of any city. This complex consists of three principal directions: ecological environment, ecological activity, and ecological society. All these directions are equally important for forming of «zero» ecocity and eco-buildings.

New complex of interconnected sciences for healthy cities creation includes the sciences about ecological, healthy, sustainable and beauty cities with high-quality environment of person's life and with environmental technologies: urban ecology, architectural ecology, building ecology, ecological infrastructure, sensory ecology, and ecological ethics. Creation of «zero» ecocity is based on inculcation of ecological thinking, ecological culture, eco-philosophy, and ecological ethics. It is possible to assert, that ecological compatibility, bio-positivity of «zero» ecocity, their life in harmony with the natural environment as allied component is the good way of the development, allowing carrying out eternal mankind's dream of unity with nature.

The fundamental concept of ecocities will be invariable: they will be in ecological equilibrium with nature, and thus to create ecologically well-founded high quality environment life for inhabitants.

Table 2. Scientific complex for «zero» ecocity and eco-buildings creation

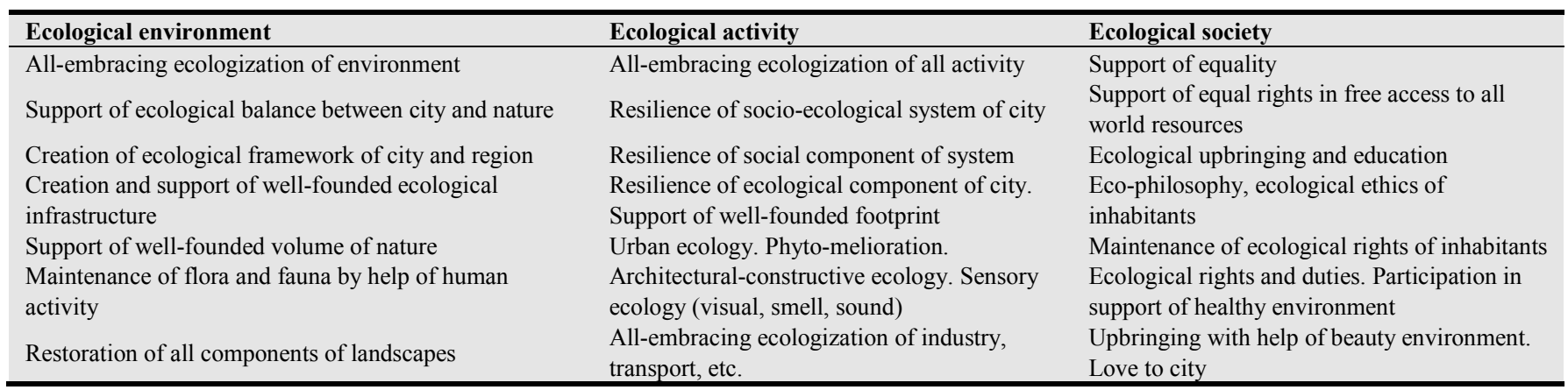

But they will differ essentially from each other by set of individual decisions - from the size of city up to a degree of use of renewable resources, from a degree of preservation of the natural environment up to use of local materials, from a degree of equality of inhabitants up to a level of satisfaction of needs of inhabitants, etc. A base of new scientific complex is ecological infrastructure (tab. 3). Ecological infrastructure is complex of natural resources, constructions and systems, providing support of environment of human life at all levels from the whole country up to cities and to separate buildings and engineering constructions. Ecological infrastructure includes interactive among themselves completely natural 
environment, quasi-natural cultural environment - cultural landscapes etc., artificial technical environment of cities, socio - psychological and socio - economic medium (tab. 3). Ecological infrastructure is the interactive among themselves mastered and natural territories, ecological framework of city and green corridors, soil - vegetative layer, biopositive and «clever» buildings, systems of phyto-melioration and permaculture, ecologically restored landscapes and ecologically reconstructed buildings, favorable perceptible city environment, favorable conditions of life. Wide ecological infrastructure can include all objects and phenomenon of Universe, which influence on environment of life - from Cosmos to deep lithosphere of Earth.

Ecological thinking includes various types of reflexive processes: understanding the personality of its place in the Universe and in the nature of the Earth (world outlook reflexion); awareness of the ideological problems of interaction of humanity and nature (methodological reflection); select the new value orientations and ideals (personal-psychological reflection); creating the modern scientific picture of the world (reflection out of paradigm); choice of strategy activities (person-organizational reflection), etc. Ecological psychology is an interdisciplinary concept of ecological consciousness. Awareness of oneself as an individual in the global system of nature is a complete system of different mechanisms of reflective thinking. Environmental thinking is the ideological reflection aimed at understanding the scientific picture of the world, the co-evolution of humanity and nature, to choose the new value orientations of personality, to develop environmentally beneficial human activity.

Table 3. Frame of ecological infrastructure

\begin{tabular}{lll}
\hline Artificial environment with ecologization & Completely natural environment & Quasi-natural (cultural) environment \\
\hline Technological systems with their ecologization & $\begin{array}{l}\text { All natural territories with natural flora and } \\
\text { fauna }\end{array}$ & Created by the person green areas \\
$\begin{array}{l}\text { Traditional infrastructure with ecologization } \\
\begin{array}{l}\text { Systems warning and liquidating adverse } \\
\text { phenomena }\end{array}\end{array}$ & $\begin{array}{l}\text { Natural ecological framework with ecological } \\
\text { corridors }\end{array}$ & Ecological built environment \\
Socio-economic and socio-psychological medium & & \\
\hline
\end{tabular}

Urban ecology is most general science for ecological design of territories of cities and towns. It includes the decisions of ecological problems of big territories. The major problem of urban ecology is creation of the ecological framework of big territory. Ecological framework of Earth is system of large natural territories, which are interconnected by ecological corridors, indissoluble interrelation of which allows supporting ecological equilibrium, environment of life, and biological variety. Natural and improved cultural landscapes are the basis of ecological framework of city, united by "green corridors", "green wedges" sites of nature of various areas. The ideal ecological framework of city should look like a network with "cells" of nature including all components of natural and cultural landscapes in regular intervals distributed on the area - forests, parks, rivers, lakes, meadows, hollows, heights, squares, gardens and so forth. At their absence, it is necessary to create cultural green corridors that can be accompanied by formation of new "cells" of framework if their area on territory of city is small or if their number is insignificant.

Architecturally - constructive ecology contains two complexes of ecology knowledge's: complex of general knowledge that allows forming the ecological thinking of builders, and complex of special ecology thinking for ecologization of building. Resilient environment of life of person presupposes a presence of conditions providing long, practically endless, satisfaction of essential (prime) and other ecologically well-founded needs necessary for human life, raising quality of the life, forming the harmonious social environment. For achievement of ecological equilibrium and high quality environment of life, it is necessary to keep ecologically well-founded territory of nature in all its biodiversity, to change interaction of person and technologies with nature. «Zero» eco-buildings should be multifunctional, and alongside with the basic function (apartment house, industrial building, seashore construction etc.) can carry out one or several nature protection functions. «Zero» eco-buildings can use the renewable energy; they can clean polluted air and water through surfaces of buildings contacting with air and underground water by way of setting on all surfaces of walls of filters with compulsory circulation of polluted air and water(fig. 2).

In «zero» ecocity may be used intelligent («clever») buildings.

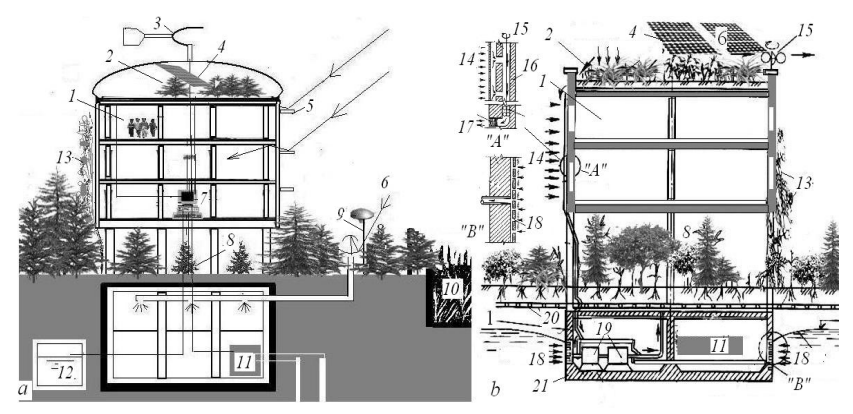

Figure 2. "Zero" buildings: $a$ - with use of renewable energy; $b$ - with cleaning of polluted air and water: 1 - overground building; 2 - winter garden; 3 - natural ventilation (such as a hood); 4 - solar battery; 5 - receipt of light due to reflecting a venetian blind; 6 - daylight into basement; 7 - computers for receipt of the data from devices (sensors); 8 - trees under building; 9 solar energy for night illumination; 10 - "living machine" for black water cleaning; 11- thermal pump of system of geothermal heating; 12 - collection of "grey" water; 13 - vertical greenery; 14 - polluted air; 15 - wind turbine; 16 - canal for air; 17 -filter; 18 - polluted water; 19 -pump; 20 - perforated pipe; 21 - underground part of building; “ $A$ ”, “ $B$ ”- details 
They supervise constantly through system of sensors the condition of the external and internal environment and at deviation of parameters from norm includes the effectors clearing, for example, environment from pollution, or improving other parameters. The «clever» building should create optimum conditions for people, which are in it. Automatic sensors serve for support of normal physical and psychophysiologic conditions of people environment. Such building contains sensors (converters), located in places of the best selection of the information on parameters of physical and psychophysiologic conditions of people (they determine blood pressure, frequency of breath and heartbeat, a timbre and loudness of a voice, a condition and color of iris of the eyes, weight and growth of the person etc.).

They transmit these parameters in the computer. The computer analyzes normal and current parameters based on medical expert system (MES) and at deviation from norm, it signals about the beginning of illnesses. On the basis of the data incorporated in memory the computer gives out signals on the executive mechanisms giving in rooms medical aerosols and the appropriate additives for smells; in potable water, in water for douche or bath - medicinal additives; creating necessary (raised or lowered) temperature and humidity indoors; giving out on the monitor in kitchen of the recommendation for a meal; including appropriate (the soothing or stimulating music, appropriate holographic or other pictures on walls; it allows to support in due time health of the person and to remove a psychological pressure (fig. 3).

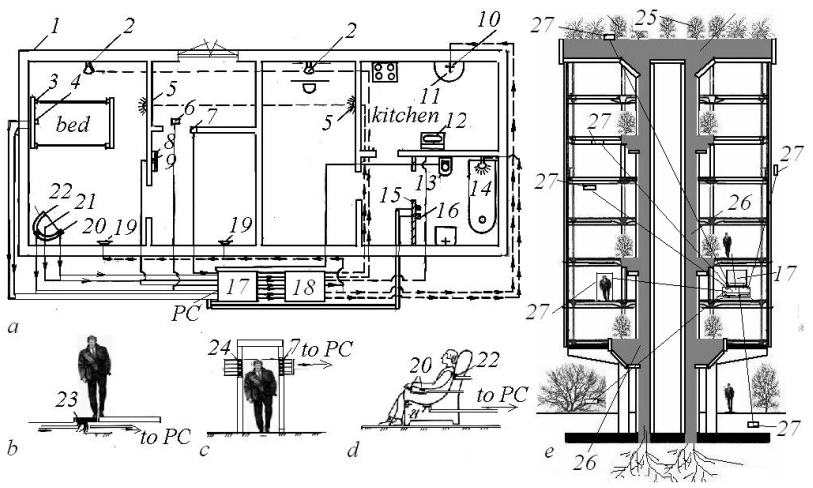

Figure 3. Plan of intellectual home with the indication of the locations of detectors (sensors) and effectors (executive mechanisms) (a); details (b-d); soil-filled building (e): 1 - external wall; 2 - spray for supply of aerosols; 3 resistive-strain sensors on bed; 4 - sensor (receiver) of exhaled air; 5 - lighter with color filters; 6 - sensors of weight of body in floor; 7 - photo resistors in a jamb of door; 8 - mirror; 9 - transmitting color TV camera; 10 - supply of medicinal additives in potable water; 11 - wash-bowl; 12 - display with conclusion of the data on a recommended diet and a healthy way of life; 13 the sensorbl in "clever» toilet; 14 - tube for introduction of medicinal additives in water in douche and in bath; 15 - thermo vision camera; 16 equipment for control by method Kirlian - effect; 17 - system of executive mechanisms; 18 - microprocessor; 19 - loudspeaker; 20 -sensors of blood pressure and heartbeat; 21 - resistive-strain sensors in sitting of armchair; 22 - microphone; 23 - sensors of shuffling in floor; 24 - sources of light; 25 green roof; 26 - soil in vertical canals; 27 - soil on floors

Intellectual buildings can realize such functions:

1. Monitoring and optimization of use of all resources (energy, gas, drinking water, etc.) for reduction of their consumption.

2. Control and support of ecologically well-founded quality of internal and external environment inside and outside of buildings.

3. Control of condition of buildings and construction materials, of ground and foundations, of static and dynamic loads and peculiar influences.

4. Control and support of good condition of health of inhabitants.

5. Monitoring of external natural actions on building (earthquake, etc.).

6. Ecological education in educational institutions.

7. Monitoring of environment inside and outside of buildings for protection against criminals (undesirable and dangerous people).

Cities with intellectual systems can realize such functions:

1. City control and support of good condition of health of inhabitants with integration of all intellectual buildings and hospitals in united net.

2. City control of infrastructure including traffic current, commodity circulation, energy and other resources flows, currency etc. for support of well-founded functioning of city.

3. City control of condition of social-ecological system by way of intellectual social networks.

4. City control and support of well-founded condition of nature.

5. City control of extraordinary situations and timely interference for support of safety.

Future intellectual functions can be added at global level:

1. Control and timely interference for support of ecological balance and preservation of well-founded volume of nature in scale of planet.

2. Control of near, deep space, and timely interference for support of safety of planet.

3. Control of extraordinary situations in scale of planet and timely interference for support of safety of planet.

Intellectual building contains three basic interconnected systems:

1. System of receptors (of devices, which measure various parameters of environment, persons, and buildings).

2. Computer with loaded in it program (expert system medical MES, resources consumption RES, environmental EES, etc.) which serves for analysis and evaluation of incoming data.

3. System of effectors (actuating devices) which serve for putting in order (in the norm) of all parameters. This system allows with the help of feedback to watch results of work of effectors (fig. 1).

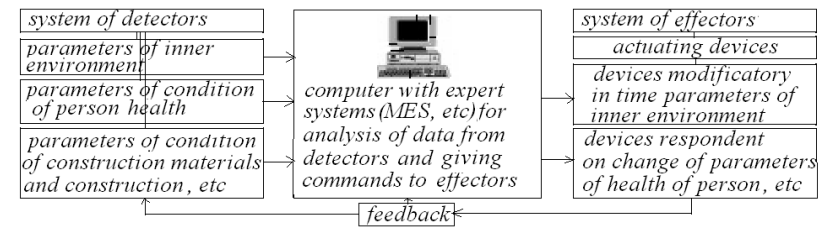

Figure 4. Scheme of functioning of intellectual building 


\section{Conclusion}

Undoubtedly, the «zero» ecocities and eco-buildings are the attractive future of humankind. Previously mentioned new scientific complex of ecocity creation may help to form new ecological thinking of future specialists - authors of «zero» ecocities. All-embracing ecologization of all directions of people thinking and activity may be the basis of creation of future realistic ecocities.

\section{References}

[1] Tetior A. Building ecology. Kiev: Builder, 1992.

[2] Tetior A. Ecocity: problems, solutions. - Tver: «Publishing house», 2005
[3] Tetior A. Ecological infrastructure. - Moscow: «Koloss», 2003.

[4] Tetior A. «Zero» ecological home. - Moscow: «MSUEE», 2010.

[5] Tetior A. Resilience of life environment. - Moscow: «Nature», 2003.

[6] Tetior A. Ecocity: problems, solutions. - Tver: «Publishing house», 2005.

[7] Tetior A. Architectural-building ecology. - Moscow: «Academy», 2009.

[8] Tetior A. Ecologization of thinking and activity of mankind. Moscow, «MSUEE», 2014.

[9] Tetior A. Ecology of city environment. - Moscow: «Academy», 2013. 